\title{
TRANSIENT STABILITY ANALYSIS OF DISTRIBUTED GENERATION
}

\author{
S.Sivanandan ${ }^{1}$, S.Jaisiva ${ }^{2}$, R.Vinoth ${ }^{3}$, A.Mahendran ${ }^{4}$ \\ ${ }^{I}$ Assistant Professor, Dept. of Electrical \& Electronics Engineering, IFET College of Engineering, Villupuram, \\ Tamilnadu, India \\ ${ }^{2}$ Assistant Professor, Dept. of Electrical \& Electronics Engineering, IFET College of Engineering, Villupuram, \\ Tamilnadu, India \\ ${ }^{3}$ Assistant Professor, Dept. of Electrical \& Electronics Engineering, IFET College of Engineering, Villupuram, \\ Tamilnadu, India \\ ${ }^{4}$ Assistant Professor, Dept. of Electrical \& Electronics Engineering, IFET College of Engineering, Villupuram, \\ Tamilnadu, India
}

\begin{abstract}
The commonly used distributed generation technologies include wind generators, photo voltaic and biomass generators with their sizes varying between $K W$ to a few $M W$. Due to increased demand in power supply the role of these distributed generators become inevitable in power systems. This work deals with analyzing the transient stability indicators i.e., the variation of distributed generator terminal voltage, load side terminal voltage and rotor speed during different fault conditions when it is connected to the electric grid along with storage device (lithium-ion battery). Three bus test system is considered for the analysis and MATLAB / Simulink power systems tool is used as a software tool to show the performance.
\end{abstract}

Keywords:- Transient Stability, Distributed Generator, Lithium Ion Battery, Terminal Voltage and Rotor Speed Deviation.

\section{INTRODUCTION}

Distributed generation is getting a lot of focus in recent years due to various energy and environmental concerns. Unlike the conventional generators, the distributed generators use both non-renewable and renewable sources of energy to generate electricity. Major technical and economic issues arise when these DG's are interconnected with the electric grid. The technical issues include stability, power quality, protection issues and voltage fluctuations. It has to be noted that certain renewable generators such as wind and solar do not produce power at a constant rate since they are dependent on the natural forces. This makes the use of storage devices very essential.

There has been increased point up in the decades on the concept of smoothing intermittent output of distributed generation (DG) using energy storage [1]. DGs can be defined as the concept of connecting generating units of small sizes, between several $\mathrm{kW}$ to a few MW. The primary source of energy for these generators can be the traditional non - renewable sources such as gas or the renewable sources such as wind, solar, hydro, and biomass [3]. These generators are connected either to the medium voltage or low voltage sections of the electric grid. Most often they are connected near the load centers or the low voltage networks.

In case of certain renewable technologies, such as wind turbines and solar panels, the output power depends upon the availability of renewable resource and therefore may not always be constant. In such cases, in order to augment the DGs during low power periods, energy storage devices are used [3]. Other than wind and solar, storage can help in smoothing the power in conjunction with biomass especially for rural combined heating and power applications. These devices store energy during periods of high power or low demand and use the stored energy to supply the excess loads during periods of low power. Different types of energy storage devices that are used in a distributed environment include batteries, ultra capacitors, flywheels, fuel cells and superconducting magnetic energy storage [4]-[7]. In addition to supporting the DGs during peak demand, the storage devices may also help in improving the overall stability of the entire system. These energy storage devices are connected to the electric grid by means of suitable power conversion devices [8]-[10].

Certain DG techniques such as wind and solar, do not output constant power at all times. In such cases, storage of power for later use becomes essential. The energy storage devices store power from the DG's during times of normal output and low loads. This stored energy can be used at time when there is no DG output or during periods of high demands. The storage device that needs to be used depends upon the application, amount of storage needed and the duration of storage. Most of the storage devices are DC, so we need power electronic interfaces to connect them to the $\mathrm{AC}$ system.

DG's can operate in two modes namely stand-alone and grid connected. The grid connected mode has drawn a lot of attention and analysis recently, due to its impacts on the grid. Though the DG has a lot of advantages, it also has some negative impacts especially when connected to the grid. 
The most critical technical issue is the stability of the system. There have been a number of studies on the both the steady state and the transient stability impacts of DG on systems. As mentioned earlier, energy storage devices also have significant impact on the system. Based on the indicators and approach selected in the references, a procedure to analyze the stability has been obtained. This work also involves modeling of two energy storage devices, battery and ultra-capacitor.

The thesis is organized as ten sections including Introduction section as 1 . In section 2 , basics of distributed generation are discussed and Impacts of DG on transient stability are discussed in section 3 . In section 4 energy storage device such as Lithium-Ion is explained briefly. Section 5 deals with the modeling of the test system that has been used for the analysis. Section 6 deals with the interfacing of Power Electronic Component, Transient Stability Analysis of the system defined in detail in section 7. Procedure for analyzing transient stability is discussed briefly in section 8 . Results are discussed briefly and clearly in section 9. At last Conclusion have been discussed in section 10 .

\section{DG TECHNOLOGIES}

There are numerous DG technologies that are gaining popularity recently. A few of the most commonly used ones are the Internal Combustion engines, micro turbines, wind, solar panels, fuel cells and biomass.

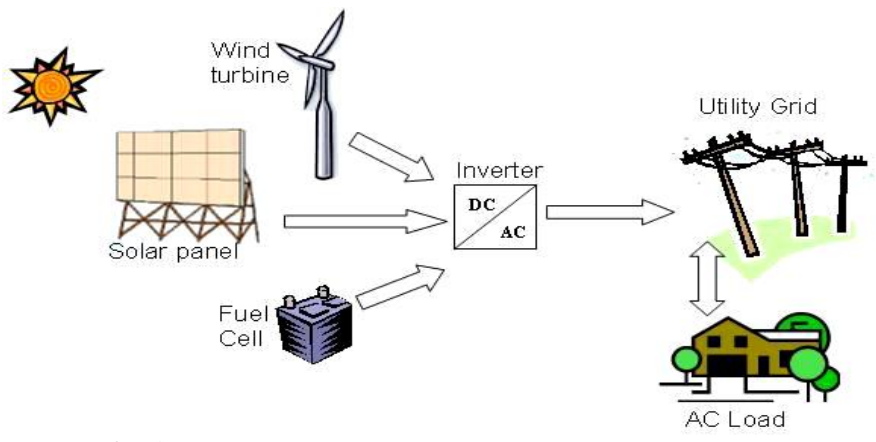

Fig.1. Representation of Distributed generation

\section{TRANSIENT STABILITY IMPACTS OF DG}

As mentioned in the previous section interconnection of DG to the grid impacts the stability of the grid to a great extend. In the earlier DG studies, the impacts on transient stability were almost neglected since the most important objective at that point was to produce electricity from renewable energy. When the size of DG is quite small, its impacts on the transient stability will be negligible and therefore can be neglected. But with the increase in the number of DG's it becomes essential to analyze the transient stability. It is only in the recent years that greater focus is given on the stability impacts due to increasing usage of DG's and their bigger sizes.

In reference [11], the transient stability of the New England test system is analyzed. The analysis includes asynchronous generators, controlled and uncontrolled synchronous generators as well as controlled and uncontrolled power electronic converters. In this approach a fault is applied to the system for $150 \mathrm{~ms}$ and the response of the different generator technologies with different penetration levels are monitored.

The response of these generator techniques are analyzed by means of three indicators namely rotor speed deviation, oscillation duration and the terminal voltage. This study proved that increase in the number of DG's improved the stability of the system irrespective of the type of technology used.

Similar approach has been used in reference [12], to analyze the angle, frequency and voltage stability of a 245-bus system. In this study, the power angle between two generators, the deviation in frequency and voltage deviation is analyzed when a fault of $100 \mathrm{~ms}$ is applied to the system. Similar to the previous work, in this also it was seen that with more DG percentage, the stability of the system improves.

\section{ENERGY STORAGE DEVICE - LITHIUM- ION BATTERY}

Batteries are one of the most efficient and economic devices for storing energy. There are wide varieties of batteries that can be used for energy applications. The most general requirements of a good battery are as given below.

- It has to supply adequate power to meet the load demand, when needed.

- It has to last for a considerably long period of time and should be economical.

Generally, batteries can be defined as sources of energy that supplies the required power by converting chemical energy into electrical energy. Battery is a term that is commonly used to indicate a group of electrochemical cells that are interconnected in series or parallel. Fig.2. explains the working principle of each cell.

The anode and the cathode are separated by the electrolyte, which is either a solid or liquid. The two electrodes are connected through an external device. During the process of energy conversion, oxidation takes place at the anode and reduction takes place at the cathode. During the discharging process the electrons is passed from the anode to the cathode and the electrons are made to flow from the cathode to the anode during the process of charging. The difference in the potential energy is measured in terms of volts and is known as the terminal voltage of the battery or the battery voltage. The voltage of an individual cell is generally less and therefore a number of cells are connected in series to obtain a higher voltage level. 


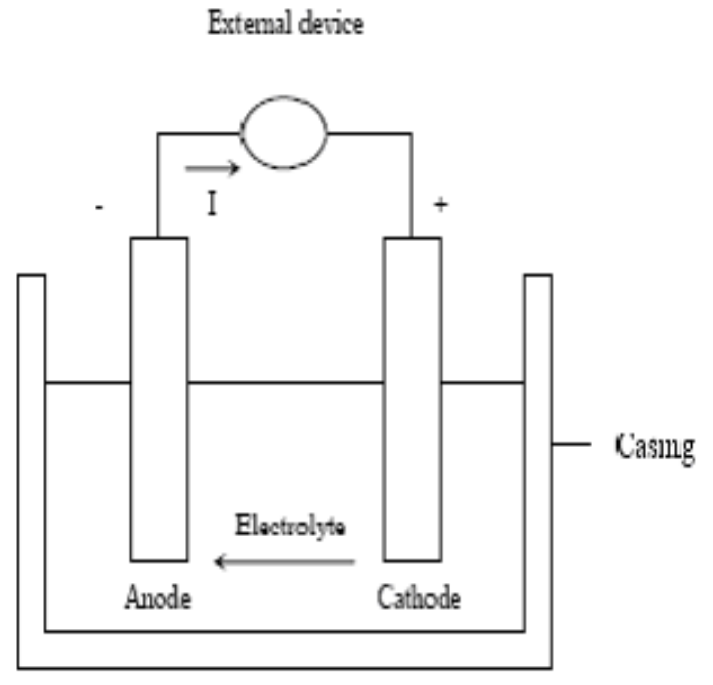

Fig.2. Principle of operation of an electrochemical cell

\subsection{Lithium-Ion Cell}

Lithium-Ion cell is one of the most efficient and commonly energy storage device. The Lithium-Ion cell consists of a carbon anode, a metallic cathode and an organic electrolyte. In most of the commercially available cells the anode is graphite and the cathode is made up of a material that is capable of allowing lithium to penetrate in and out of it. The reactions at the anode and the cathode can be described by the following equations:

At Anode: $\mathrm{Li} \times \mathrm{C} \leftrightarrow \mathrm{C}+\mathrm{xLi}^{+}+\mathrm{xe}$

At Cathode: $\mathrm{Li} 1-\mathrm{xMO} 2+\mathrm{xLi}^{+}+\mathrm{xe} \leftrightarrow \mathrm{LiMO} 2$

where,

$\mathrm{C}$ is carbon (graphite) and $\mathrm{M}$ can be either $\mathrm{CO}$ or $\mathrm{Ni}$ or a mixture of both.

The electrolyte used in the Li-Ion cell is selected based on two criteria:

- It has to be stable and efficiently form a solid electrolyte interface (SEI) on the anode material (graphite)

- The electrochemical potential of the electrolyte has to range from $0 \mathrm{~V}$ to at least $4.3 \mathrm{~V}$. Some of the most commonly used electrolytes for Li-ion cells depend on LiPF6 and a mixture of binary solvent. The major concern while selecting the electrolytes is their flammability. Certain additives are added to the electrolytic solution to make sure that the flammability is lowered.

\subsection{Lithium-Ion Cell Performance:}

The general parameters of the cell such as specific energy, energy density and cycle life depend on the type of cathode that is used
Table.1 Performance of Li-ion battery ( 8 single cells) for $\mathrm{Ni}-\mathrm{Co}$ and $\mathrm{Mn}$ cathodes

\begin{tabular}{|c|c|c|c|}
\hline \multicolumn{2}{|c|}{ Parameter } & $\begin{array}{l}\text { Ni-Co } \\
\text { positive }\end{array}$ & $\begin{array}{l}\text { Mn } \\
\text { positive }\end{array}$ \\
\hline $\begin{array}{l}\text { Battery } \\
\text { (kWh) }\end{array}$ & Energy & 2.3 & 2.5 \\
\hline $\begin{array}{l}\text { Specific } \\
(\mathrm{Wh} / \mathrm{kg} \text { ) }\end{array}$ & energy & 128 & 122 \\
\hline $\begin{array}{l}\text { Energy } \\
(\mathrm{Wh} / \mathrm{L})\end{array}$ & density & 197 & 255 \\
\hline $\begin{array}{l}\text { Energy } \\
(\%)\end{array}$ & efficiency & 98 & 96 \\
\hline Cycle life & (cycles) & 900 & 1200 \\
\hline
\end{tabular}

The values of different parameters for two different cathode types are given in Table.1.It can be seen from the table that using Mn cathode results in better performance as compared to the Ni-Co cathode.

\subsection{Battery Design Considerations}

The term battery denotes a group of individual cells connected in a series or parallel connection.

Designing a battery bank depends on the following conditions:

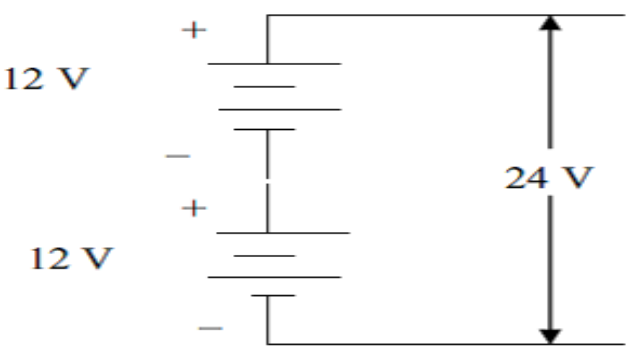

Fig.3.Series connection of cells

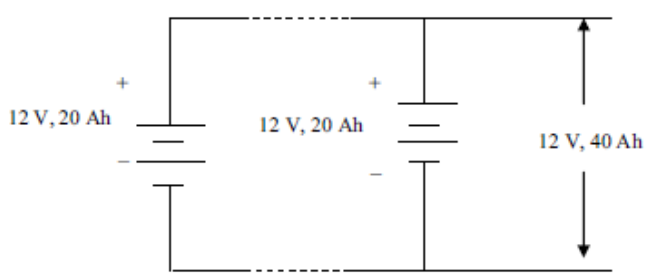

Fig .4 Parallel connections of cells

- $\quad$ Bank voltage - The total voltage of the bank is met by connecting the cells in series.

- $\quad$ Bank capacity - Connecting the cells in parallel can increase the capacity of the battery bank. Parallel connection increases only the capacity whereas the voltage level of the bank remains the same as shown in Figure.

\section{TEST SYSTEM}

This chapter deals with the modeling of the test system that has been used for the analysis. The characteristics of the test system and its components are explained. Power electronic 
interface used for connecting the storage device to the $\mathrm{AC}$ system are also presented. In this analysis there are certain indicators selected for the transient stability analysis. These indicators have been explained in this chapter.

One line diagram of test system through which the analysis was done is shown below.

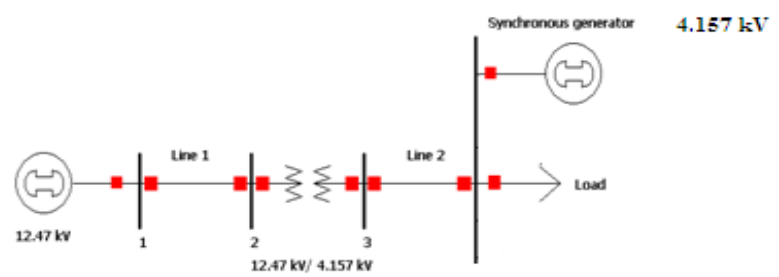

Fig.5.One line diagram of test system

As it can be seen from Fig.4. The test system consists of a main source (feeder) and distributed source which is connected at bus number three where the operating voltage is $4.157 \mathrm{kV}$.

\section{POWER ELECTRONIC INTERFACE}

Basically the lithium ion battery is a DC device and therefore it needs suitable power conditioning devices to be interfaced with the $\mathrm{AC}$ system. It has been already mentioned that the energy storage devices discharge the stored energy at times when the load is unmet by the distributed generators. During this period the DC power from the storage device needs to be converted into $\mathrm{AC}$ power in order to be able to supply the load. On the other hand, when there is enough power to supply the loads, the $\mathrm{AC}$ power from the grid is used to charge the storage device. In practical applications, the energy storage device is connected to the system by means of bidirectional converters since the cost of using two different converters is high. A bidirectional converter acts as both a rectifier and an inverter based on the direction of current flow. The basic scheme of a energy storage interface system is shown in fig.5.

In the scheme presented in fig.5, the energy storage system is connected to the grid through the voltage source inverter and a DC link capacitor. The energy storage device is connected at the DC side of the converter. The general working principle of the converter is as below:

- When the power demand from the grid is lesser than the power generated by the DG, the storage device absorbs power and is therefore charged.

- When the power demand is more than the power delivered by the DG, the storage device supplies the additional power that is needed.

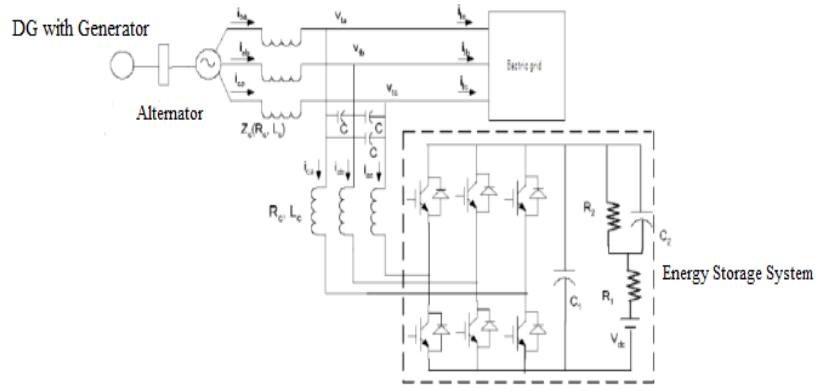

Fig.6. Interconnection scheme for storage device

The voltage source converter is controlled by means of two proportional-integral (PI) controllers in order to maintain the terminal voltage at the $\mathrm{AC}$ side of the converter at the required.

\section{TRANSIENT STABILITY ANALYSIS OF THE SYSTEM}

Transient stability of a system is defined as the ability of the system to return back and remain in its stable operating condition following a severe disturbance. In order to analyze the transient stability of the system certain stability indicators were chosen by means of which the stability of the system was accessed. The description of these indicators, different scenarios that were considered for the analysis and the procedure to analyze stability is explained in this section.

\subsection{Transient Stability Indicators}

In order to investigate the transient stability of the test system, certain indicators have to be selected which indicate stability. The indicators selected depend upon the type of stability that needs to be monitored. In this analysis the different stability indicators are selected based on references [13].

Terminal voltage -It is known that the voltage magnitude or phase of the system changes when there is a disturbance in the system. When a disturbance is applied to the system, the terminal voltage changes and when the fault is cleared it returns back to normal. A system is said to have better voltage stability if this change in voltage is less.

Rotor speed deviation- It can be defined as the maximum change in the speed of the rotor of the machine when a disturbance is applied to the system. The degree of stability is analyzed based on the amount of deviation in the speed. The stability of a system in which the rotor speed deviation is less is considered better than a system in which the speed deviation is more. 


\section{PROCEDURE FOR ANALYZING TRANSIENT}

\section{STABILITY}

A step by step has been followed to analyze the test system.

- A fault is applied at the bus where distributed generators were connected.

- Faults were applied for two different conditions with and without energy storage device respectively.

- $\quad$ The response of the system to the fault is analyzed by means of the transient stability indicator that was chosen.

- This procedure is repeated for different types of faults.

- The response of the indicators to the fault is analyzed for the system.

\section{RESULTS AND DISCUSSIONS}

For the technical analysis, MATLAB/ Simulink have been used. Simulink has been selected due to the reason that it is user-friendly and consists of a number of ready to use models. The power system components in the Simulink library include different types of generators, loads, transformers, faults and other components, which can be used to build and analyze the necessary test system. There are no built-in energy storage models in Simulink. Though there are no built-in models of energy storage, it can easily be built using the basic blocks that are present. The response of the selected indicators are monitored and recorded by means of the scope.

Analysis is done both with and without energy storage device (Lithium-ion). This chapter presents the results of transient stability analysis with and without energy storage device. Two different fault conditions were considered for the stability analysis.

\subsection{CASE I DOUBLE LINE TO GROUND FAULT}

\subsubsection{Terminal Voltage (DG Side)}

Fig.7 shows the variation of DG side terminal voltage when double line to ground fault is applied for a period of one millisecond (1.5 -1.6) with distributed generator alone i.e. without storage device (Lithium-ion battery).

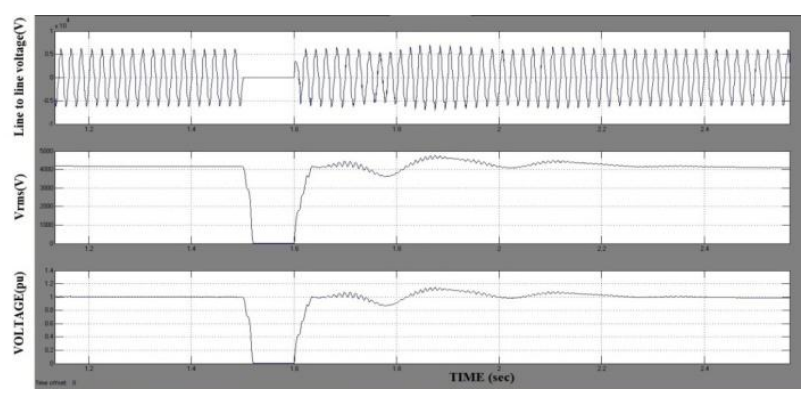

Fig.7.Terminal voltage deviation without storage device (Case I)

Fig. 8 shows the variation of DG side terminal voltage when double line to ground fault is applied for a period of one millisecond (1.5 -1.6) with distributed generator and storage device (Lithium-ion battery).

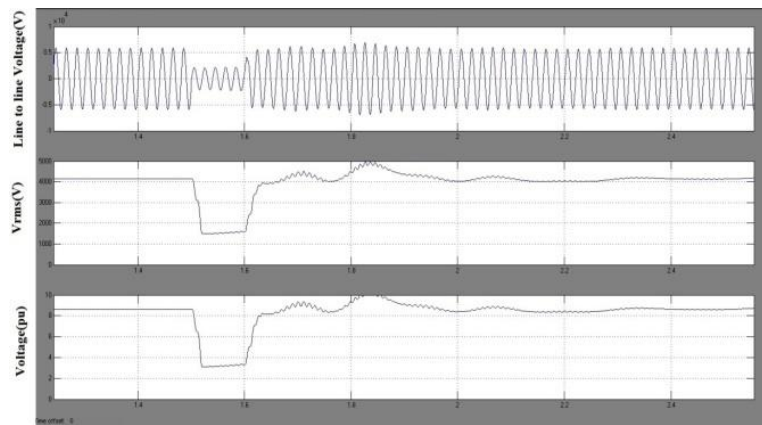

Fig.8. Terminal voltage deviation with storage device (Case I)

In Fig.6. when the double line to ground fault is applied, voltage during the fault period reduces up to $150 \mathrm{~V}$. After the time period of fault i.e. after $1.6 \mathrm{sec}$, it takes another 0.6 seconds to return to stable voltage level.

In Fig.7. for the same type of fault the fault period voltage reduces to $2 \mathrm{KV}$ which increases the security of the system, also it takes the same recovery period of 0.6 seconds after fault period.

\subsubsection{Terminal Voltage (Load Side)}

Fig.9 shows the variation of load side terminal voltage when double line to ground fault is applied for a period of one millisecond (1.5 -1.6) with distributed generator alone i.e. without storage device

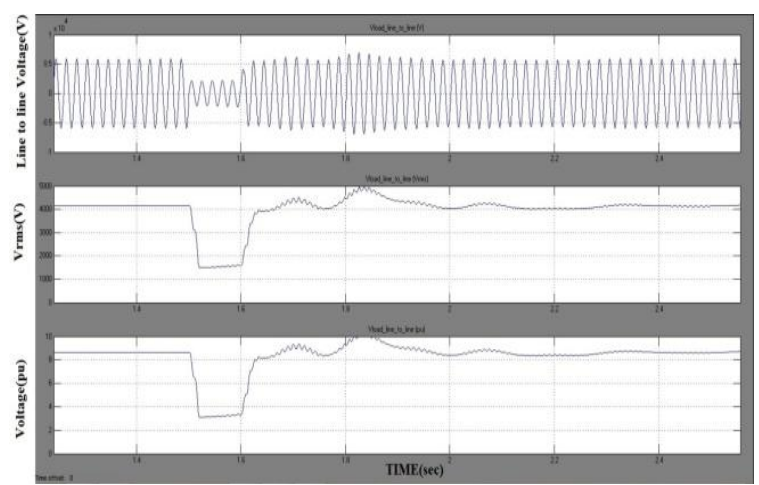

Fig.9. Terminal voltage deviation without storage device (Case I)

Fig.10 shows the variation of load side terminal voltage when double line to ground fault is applied for a period of one millisecond (1.5-1.6) with distributed generator and storage device (Lithium-ion battery). 


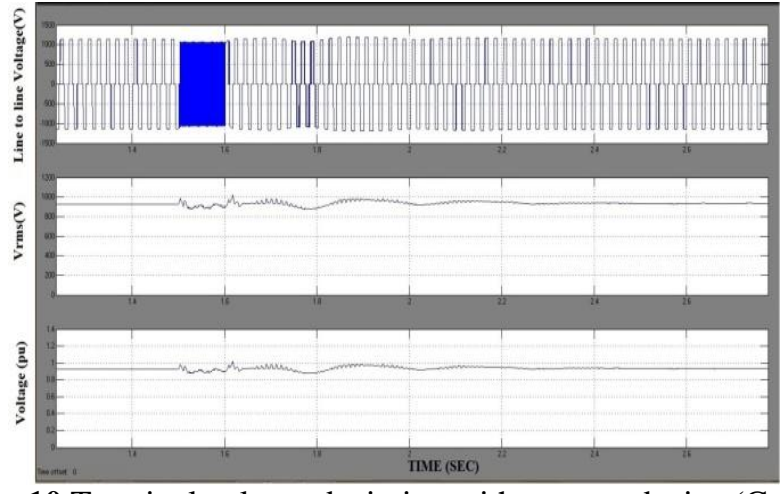

Fig.10.Terminal voltage deviation with storage device (Case I)

In Fig.9. when the double line to ground fault is applied, voltage during the fault period reduces up to $450 \mathrm{~V}$. After the time period of fault i.e. after $1.6 \mathrm{sec}$, it takes another 0.6 seconds to return to stable voltage level.

From the Fig.10. it is clear that during fault period the deviations of the voltage waveform are reduced due to the interfacing of storage device.

\subsubsection{Rotor Speed Deviation}

Fig.11. shows the deviation of rotor speed when double line to ground fault is applied for a period of one millisecond (1.5 -1.6) with distributed generator alone i.e. without storage device (Lithium-ion battery).

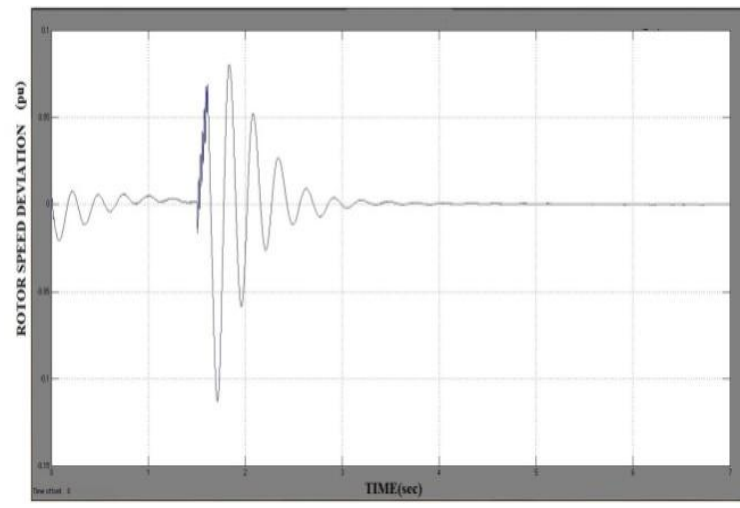

Fig.11. Rotor speed deviation without storage device (Case I)

Fig. 12 shows the rotor speed deviation when double line to ground fault is applied for a time period of one second i.e. from 1.5 second to 1.6 second with distributed generator and storage device (Lithium-ion battery).

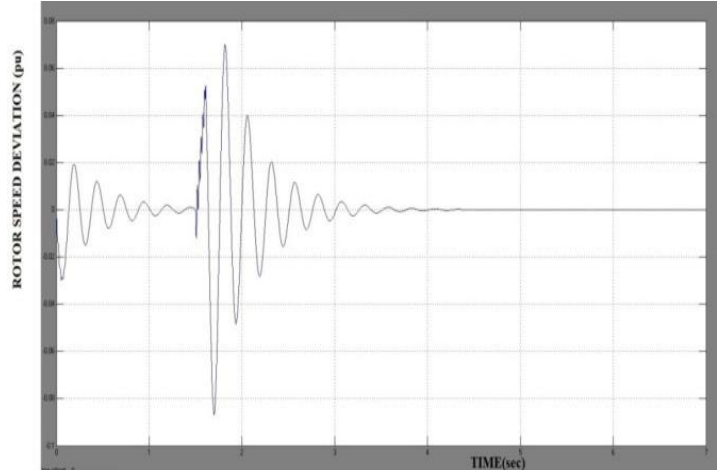

Fig.12. Rotor speed deviation with storage device (Case I)

For the system without storage device, when double line to ground fault is applied the rotor speed deviation reaches the peak value of 0.08 per unit and takes 2.4 seconds to recover to null speed deviation position. But after the storage device is interfaced to the system during fault period the peak of rotor speed deviation reaches to 0.06 per unit which is lesser than previous case, also it takes same recovery period of 2.4 seconds to reach the null deviation position

\subsection{CASE II THREE PHASE TO GROUND}

\section{FAULT}

\subsubsection{Terminal Voltage (DG Side)}

Fig. 13 shows the variation of DG side terminal voltage when three phase to ground fault is applied for a period of one millisecond (1.5 -1.6) with distributed generator alone i.e. without storage device (Lithium-ion battery).

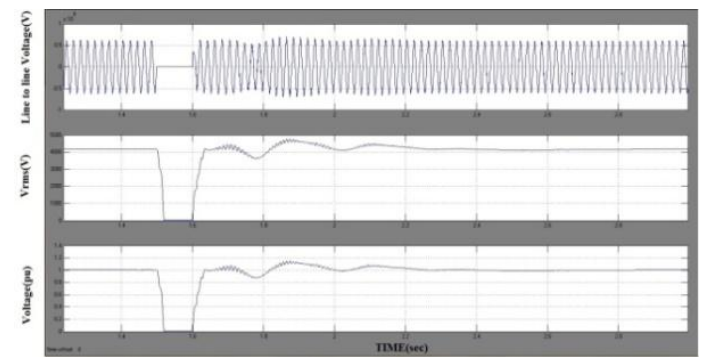

Fig .13 Terminal voltage deviation without storage device (Case II)

Fig.14. shows the variation of DG side terminal voltage when three phase to ground fault is applied for a period of one millisecond $(1.5-1.6)$ with distributed generator and storage device.

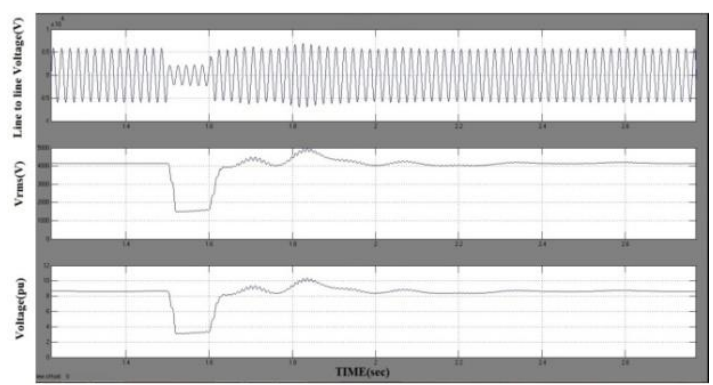

Fig.14. Terminal voltage deviation with storage device (Case II) 
In Fig.13. when the three phase to ground fault is applied, voltage during the fault period reduces up to $100 \mathrm{~V}$. After the time period of fault i.e. after $1.6 \mathrm{sec}$, it takes another 0.7 seconds to return to stable voltage level.

In Fig.14 for the same type of fault the fault period voltage reduces to $2 \mathrm{KV}$ which increases the security of the system, also it takes the same recovery period of 0.7 seconds after fault period

\subsubsection{Terminal Voltage (Load Side)}

Fig.14. shows the variation of load side terminal voltage when three phase to ground fault is applied for a period of one millisecond (1.5 -1.6) with distributed generator alone i.e. without storage device (Lithium-ion battery).

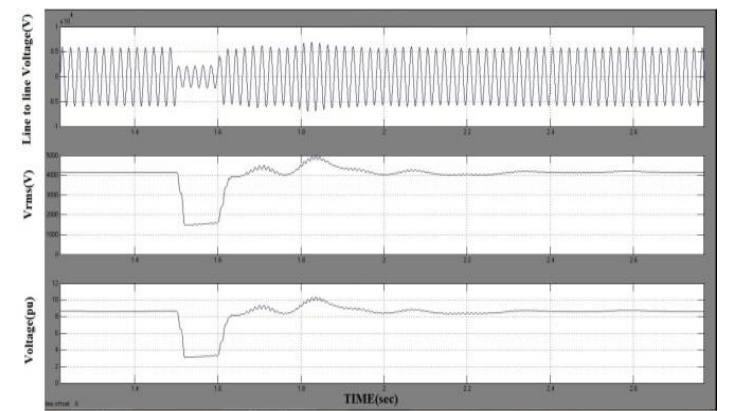

Fig.15. Terminal voltage deviation without storage device (Case II)

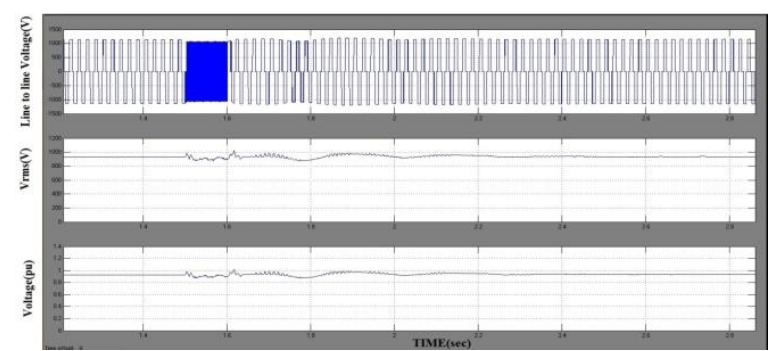

Fig.16. Terminal voltage deviation with storage device (Case II)

Fig.16. shows the variation of load side terminal voltage when three phase to ground fault is applied for a period of one millisecond $(1.5-1.6)$ with distributed generator alone i.e. without storage device (Lithium-ion battery).

In Fig.17. when the three phase to ground fault is applied, voltage during the fault period reduces up to $400 \mathrm{~V}$. After the time period of fault i.e. after $1.6 \mathrm{sec}$, it takes another 0.6 seconds to return to stable voltage level.

From the Fig.17. it is clear that during fault period the deviations of the voltage waveform are reduced due to the interfacing of storage device

\subsubsection{Rotor Speed Deviation}

Fig.18. shows the deviation of rotor speed when three phase to ground fault is applied for a period of one millisecond (1.5 -1.6) with distributed generator alone i.e. without storage device (Lithium-ion battery).

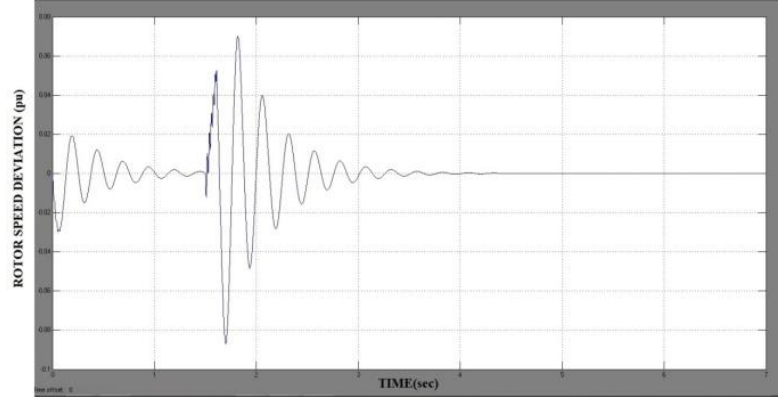

Fig.18. Rotor speed deviation without storage device (Case II)

Fig.19. shows the deviation of rotor speed when three phase to ground fault is applied for a period of one millisecond (1.5 -1.6) with distributed generator and storage device.

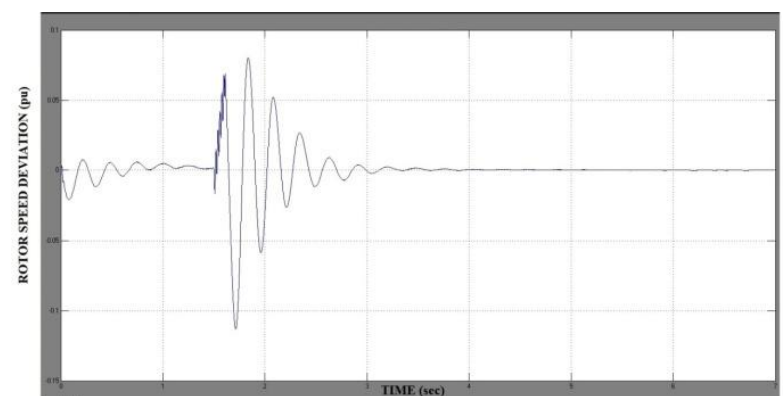

Fig.19 Rotor speed deviation without storage device (Case II)

For the system without storage device, when three phase to ground fault is applied the rotor speed deviation reaches the peak value of 0.08 per unit and takes 2.4 seconds to recover to null speed deviation position. But after the storage device is interfaced to the system during fault period the peak of rotor speed deviation reaches to 0.07 per unit which is lesser than previous case, also it takes same recovery period of 2.4 seconds to reach the null deviation position.

Table 5.1 Comparison of Simulation Results

\begin{tabular}{|c|c|c|c|c|}
\hline \multirow[b]{2}{*}{ Parameters } & \multicolumn{2}{|c|}{$\begin{array}{l}\text { Without Storage } \\
\text { Device }\end{array}$} & \multicolumn{2}{|c|}{$\begin{array}{ll}\text { With } & \text { Storage } \\
\text { Device } & \\
\end{array}$} \\
\hline & $\begin{array}{l}\text { Double } \\
\text { Line To } \\
\text { Ground } \\
\text { Fault }\end{array}$ & $\begin{array}{l}\text { Three } \\
\text { Phase } \\
\text { To } \\
\text { Ground } \\
\text { Fault }\end{array}$ & $\begin{array}{l}\text { Double } \\
\text { Line To } \\
\text { Ground } \\
\text { Fault }\end{array}$ & $\begin{array}{l}\text { Three } \\
\text { Phase } \\
\text { To } \\
\text { Ground } \\
\text { Fault }\end{array}$ \\
\hline $\begin{array}{l}\text { Terminal } \\
\text { voltage } \\
\text { (DG side) }\end{array}$ & $150 \mathrm{~V}$ & $100 \mathrm{~V}$ & $2.2 \mathrm{KV}$ & $2 \mathrm{KV}$ \\
\hline $\begin{array}{l}\text { Terminal } \\
\text { voltage } \\
\text { (Load side) }\end{array}$ & $450 \mathrm{~V}$ & $400 \mathrm{~V}$ & $750 \mathrm{~V}$ & $700 \mathrm{~V}$ \\
\hline $\begin{array}{l}\text { Rotor } \\
\text { Speed(p.u) }\end{array}$ & 0.08 & 0.08 & 0.06 & 0.07 \\
\hline
\end{tabular}

\section{CONCLUSION}

The concept of distributed generation with energy storage is not only used to meet the increased load demand but also enhance transient stability of the system when it is connected to the grid. Results obtained from the simulations 
shows that during fault period the drop in terminal voltage is decreased and also it is observed that for different fault period the deviation in rotor speed decreases when distributed generators along with storage device is connected to the grid, thus increasing the transient stability of the system.

\section{ACKNOWLEDGEMENTS}

I would like to express my greatest gratitude to the people who have helped \& supported me throughout my journal paper. Special thanks for our chairman Mr.K.V.Raja, vice chairman Mr. A. Mohammed ilyas, Secretary Mr.K.Shivram Alva. I extend my thanks to our Principal Dr.G.Mahendran, vice Principal Prof S.Matilda, Dean Placement Prof J.Asha, Head - Funded projects Prof P.Pugazhendiran.

I wish to thank my parents for their undivided support and interest who inspired me and encouraged me to go my own way, without whom I would be unable to complete my journal. At last but not the least I want to thank my friends who appreciated me for my work and motivated me and finally to God who made all the things possible.

\section{REFERENCES}

[1] Alepuz S,Busquets-Monge S,Bordonau J,Gago J,Gonzalez D,and Balcells J (2006), 'Interfacing renewable energy sources to the utility grid using a three-level inverter,' IEEE Trans. Ind. Electron., vol. 53, no. 5,pp. 1504-1511.

[2] Azmy A M and Erlich I (2005), 'Impact of distributed generation on the stability of electrical power systems,' in Proc. IEEE Power Eng. Soc. General Meeting, vol. 2., pp. 1056-1063.

[3] Carrasco J M,Franquelo L G,Bialasiewicz J T,Galvan E,Portillo Guisado $\mathrm{R}$ C,Prats $\mathrm{M}$. A.M,Leon J.I, and Moreno-Alfonso N (2006), 'Power-electronic systems for the grid integration of renewable energy sources: A survey,' IEEE Trans. Ind. Electron., vol. 53, no. 4, pp. 10021016, Aug. 2006.

[4] Gupta A,Saini R.P,and Sharma M.P (2007), 'Design of an optimal hybrid energy system model for remote rural area power generation', in Proc. Int. Conf. Electr. Eng, pp. 1-6.

[5] Haq Z(2002), 'Biomass for electricity generation in NEMS' ,presented at the National Energy Modeling System Conference, Arlington, VA.

[6] Korpaas M,Holen A.T,and Hildrum R (2003), 'Operation and sizing of energy storage for wind power plants in a market system', Int. J. Electr. Power Energy Syst., vol. 25, no. 8, pp. 599-606.

[7] Kumar A.A (2008), 'Technical and economic impacts of distributed generators and energy storage devices on the electric grid,' M.S. thesis,Dept.Electr.Comput.Eng.,Mississippi State Univ., Starkville.
[8] Mohan N,Undeland T.M, and Robbins W.R (2007), 'Power Electronics Converters, Applications and Design', 3rd ed. New York: Wiley.

[9] Selvaraj J and Rahim N.A (2009), 'Multilevel inverter for grid-connected PV system employing digital PI controller' IEEE Trans. Ind. Electron., vol.56, no. 1, pp. 149-158.

[10] Slootweg J.G and Kling W.L (2002), 'Impacts of distributed generation on power system transient stability', in Proc. IEEE Power Eng. Soc. Summer Meeting, vol. 2., pp. 862-867.

[11] A. A. Kumar, A. K. Srivastava, and N. N. Schulz, 'Impact of biomass based distributed generation and energy storage devices on the grid', in Proc. Power Syst. Conf., Mar. 2006

[12] S. A. Khateeb, M. M. Farid, J. R. Selman, and S. Al-Hallaj, 'Mechanical-electrochemical modeling of Li-ion battery designed for an electric scooter', J. Power Sources, vol. 158, no. 1, pp. 673-678, Jul. 2006.

[13] J.Wang, W. Wang, G. W. Jewell, and D. Howe, 'Design of a miniature permanent-magnet generator and energy storage system,' IEEE Trans. Ind. Electron., vol. 52, no. 5, pp. 1383-1390, Oct. 2005.

[14] S.Lemofouet and A. Rufer, "A hybrid energy storage system based on compressed air and supercapacitors with maximum efficiency point tracking (MEPT)," IEEE Trans. Ind. Electron., vol. 53, no. 4, pp. 1105-1115, Aug. 2006.

\section{BIOGRAPHIES}

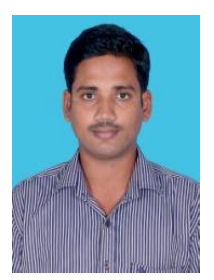

S. SIVANANDAN has completed his Bachelor's degree in Electrical and Electronics Engineering in 2010. He obtained his Post graduation degree in Power Systems Engineering in 2013 at Valliammai Engineering College, Chennai, Tamil Nadu, India. At present he is working as an Assistant Professor in IFET College of Engineering, Villupuram, Tamil Nadu, India. So far he has published one international journal and presented two papers in national conference. His research areas of interest are Distributed Generation.

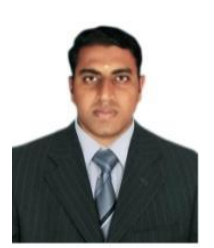

S. JAISIVA has completed his Bachelor's degree in Electrical and Electronics Engineering in 2011. He obtained his Post graduation degree in Power Systems Engineering in 2013 at SKP Engineering College, Tiruvannamalai, Tamil Nadu, India. At present he is working as an Assistant Professor in IFET College of Engineering, Villupuram. So far he has published three International Journal and presented One paper in International Conference and four National conference. His research areas of interest are Power System Optimization and Deregulated Power System. 


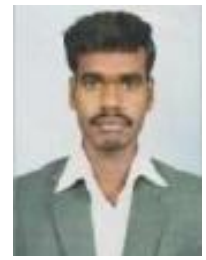

A.MAHENDRAN has completed his Bachelor's degree in Electronics and Instrumentation Engineering in 2010. He obtained his Post graduation degree in Control and Instrumentation Engineering in 2012 at St. Xavier's Catholic College of Engineering, Nagercoil, Tamil Nadu, India. At present he is working as an Assistant Professor in IFET College of Engineering, Villupuram, Tamil Nadu, India. So far he has published two International Journal and presented two papers in International Conference and two National Conference. His research areas of interest are Control System and Instrumentation.

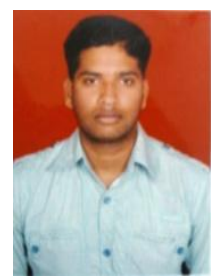

R.VINOTH has completed his Bachelor's degree in Electrical and Electronics Engineering in 2010. He obtained his Post graduation degree in Power Systems Engineering in 2013 at Sri Muthukumaran Institute Of Technology, Chennai, Tamil Nadu, India. At present he is working as an Assistant Professor in IFET College of Engineering, Villupuram, Tamil Nadu, India. So far he has published one international journal and presented two papers in national conference. His research areas of interest are Energy Market Forecasting. 